\title{
Changes in $ү \delta T$ Cells in Peripheral Blood of Patients with Ulcerative Colitis Exacerbations
}

\author{
Andrzej Gryglewski ${ }^{1}$ [D Piotr Richter ${ }^{3} \cdot$ Marian Szczepanik $^{2}$
}

Received: 7 February 2021 / Accepted: 11 June 2021 / Published online: 21 July 2021

(c) The Author(s) 2021

\begin{abstract}
The role of $\gamma \delta$ T cells in ulcerative colitis (UC) is well confirmed in experimental animals and demonstrated in many clinical observations. Recent investigations have indicated that UC is associated with several forms of immune imbalance, such as an imbalance between effector T cells and regulatory $\mathrm{T}$ cells. However, little is known about the cellular aspect of clinical colitis exacerbations. We observed 140 patients with histologically confirmed UC over the course of 8 years. We investigated the percentage of $\gamma \delta \mathrm{T}$ and $\alpha \beta T$ cells in peripheral blood of patients and also the expression of various surface markers (CD25, CD54, CD62L). Patients were assembled into stable colitis and exacerbated colitis groups. The percentage of $\gamma \delta \mathrm{T}$ and $\alpha \beta \mathrm{T}$ cells was evaluated by Ortho Cytorone Absolute flow cytometer. In patients with exacerbated colitis we observed a decrease of $\gamma \delta \mathrm{T}$ cells in peripheral blood and an increased ratio of $\alpha \beta \mathrm{T} / \gamma \delta \mathrm{T}$. Additionally, we found that exacerbation results in a significant increase of percentage of $\gamma \delta \mathrm{TCD} 25, \gamma \delta \mathrm{TCD} 54$ and $\gamma \delta \mathrm{TCD} 62 \mathrm{~L}$ lymphocytes in peripheral blood when compared to patients with stable colitis. Exacerbation of ulcerative colitis results in a decreased percentage of $\gamma \delta \mathrm{T}$ cells in peripheral blood with increase of CD25, CD54 and CD62L expressing $\gamma \delta \mathrm{T}$ cells. This may represent the effect of cell activation and migration, similar to that observed after the surgical trauma. We hope that this observation may help to predict exacerbations in colitis patients.
\end{abstract}

Keywords Immunosuppression · Ulcerative colitis · Colitis exacerbations $\cdot \gamma \delta \mathrm{T}$ lymphocytes $\cdot \alpha \beta \mathrm{T}$ lymphocytes

$\begin{array}{ll}\text { Abbreviations } \\ \text { UC } & \text { Ulcerative colitis } \\ \text { CD } & \text { Crohn's disease } \\ \text { IBD } & \text { Inflammatory bowel disease } \\ \text { TCR } & \text { T cell receptor } \\ \text { mAbs } & \text { Monoclonal antibodies }\end{array}$

Andrzej Gryglewski

msgrygle@cyf-kr.edu.pl

$\bowtie$ Marian Szczepanik

marian.szczepanik@uj.edu.pl

1 Department of Anatomy and Department of General Surgery, Gastroenterology, Oncology and Transplantology, Jagiellonian University Medical College, Kraków, Poland

2 Department of Medical Biology, Jagiellonian University Medical College, Kraków, Poland

3 Department of General Surgery, Gastroenterology, Oncology and Transplantology, Jagiellonian University Medical College, Kraków, Poland

\section{Introduction}

Inflammatory bowel disease (IBD) in humans, such as ulcerative colitis (UC) and Crohn's disease (CD), are chronic, relapsing inflammatory diseases of the digestive tract. UC is a chronic inflammatory disease of the colon with largely unknown causes and affects approximately 900,000 people in the United States, 1.5 million people in Europe, and over three million people worldwide, mainly of Caucasian descent (Armuzzi et al. 2020). UC onset occurs predominantly in young adults aged 20-40 years, with no difference between males and females (Ji et al. 2016).

The disease when diagnosed can be classified as stagnant or exacerbated. Occurring UC exacerbations deteriorate patients' life quality and increase the risk of complications. The pathogenesis of UC involves genetic factors, an aberrant immune reaction, environmental factors, and intestinal microbiota (Hanauer 2006; Sartor 2006). The immune response reflects defects in both innate and adaptive immunity. Defects of the innate immune response lead to inappropriate responses to commensal gut microbiota including the production of various cytokines promoting Th2-mediated 
immune response (Mayer 2010; Sanchez-Munoz et al. 2008). More recent findings show enhanced expression of thymic stromal lymphopoietin in mucosal lesions of UC patients in which Th2 cytokine production is predominant (Tanaka et al. 2010). Interestingly, Pastorelli et al. (2010) showed a specific increase of mucosal interleukin (IL)-33 in active UC suggesting that this cytokine may be a critical mediator in the pathogenesis of UC. Presently, we provide the better quality of life of patients, by preventing disease recurrence using a variety of medications. This increases the importance of early diagnosis of disease recurrence.

There is a large number of animal experiments that hint at the etiology of UC. These studies describe the pathological behavior of various immune cells in animal models of UC. Interestingly, intrarectal trinitrobenzene sulfonic acid administration to SJL/J or C57BL/10 mice induces a transmural colitis mainly driven by a Th1-mediated immune response and characterized by infiltration of the lamina propria with $\mathrm{CD}^{+} \mathrm{T}$ cells, neutrophils, and macrophages, whereas oxazolone colitis is characterized by robust IL-13 production originating from lamina propria $\mathrm{CD} 4^{+}$natural killer T cells (Kiesler et al. 2015). A major step forward in the development of murine models of intestinal inflammation came with the discovery that adoptive transfer of naïve $\mathrm{CD} 4^{+} \mathrm{T}$ cells $\left(\mathrm{CD} 4^{+} \mathrm{CD} 45 \mathrm{RB}^{\text {high }} \mathrm{T}\right.$ cells) from donor mice into syngeneic immunodeficient SCID or Rag $1^{-/-}$recipient mice causes a wasting disease and a primarily colonic inflammation (Kiesler et al. 2015). Severe colitis could, however, be induced in nude mice by transfer of activated/ Th1 CD4 ${ }^{+} \mathrm{CD}_{45 \mathrm{RB}^{\text {low }}} \mathrm{T}$ cells, whereas intraepithelial lymphocytes may play an important role in suppressing the development of chronic colitis in this model (Laroux et al. 2004). Nevertheless, transcription factor T-box (T-bet) deficient Th cells efficiently induce colitis, as reflected by weight loss, diarrhea, and colon histopatology. Interestingly, T-bet deficient Th cells differenciate into Th1/Th17 cells, able to express interferon- $\gamma$ and IL-17A upon restimulation (Zimmermann et al. 2016). Most authors agree that $\gamma \delta \mathrm{T}$ cells play an important role in inflammatory response in the colon (Johnson et al. 2020; McCarthy and Eberl 2018). T lymphocytes can be divided into two sub-populations according to the antigen receptor they express: the $\alpha \beta T$ cells and $\gamma \delta \mathrm{T}$ cells. $\alpha \beta T$ cells involved in adaptive immune response are the largest population of $\mathrm{T}$ lymphocytes in peripheral blood, where they account for up to $95 \%$ of circulating $\mathrm{T}$ cells (Catalan-Serra et al. 2017). In both humans and mice, $\gamma \delta T$ cells comprise a minor part (1-5\%) of the circulating $\mathrm{T}$ cell compartment found in blood and secondary lymphoid organs (Nielsen et al. 2017). These cells belong to the first line of defense in the epithelia, as well as they play an important role in immunoregulation. $\gamma \delta \mathrm{T}$ cells can be classified into three populations: $\mathrm{V} \delta 1^{+}, \mathrm{V} \delta 2^{+}$(also known as $\mathrm{V} \gamma 9 \mathrm{~V} \delta 2$ ) and $\mathrm{V} \delta 3^{+}$. $\mathrm{V} \delta 1^{+} \mathrm{T}$ cells are predominant in epithelia and play a crucial role in epithelial regeneration, whereas $\mathrm{V} \delta 2^{+}$ $\mathrm{T}$ cell population is predominant subtype in peripheral blood and has cytotoxic activity (Catalan-Serra et al. 2017). V $\delta 3^{+}$ $\mathrm{T}$ lymphocytes are present in the intestinal mucosa and they constitute only about $0.2 \%$ of $\mathrm{T}$ lymphocytes in the peripheral blood (Catalan-Serra et al. 2017). It was shown that blood from CD patients included an increased percentage of gut-tropic integrin $\beta 7$-expressing V $82^{+} \mathrm{T}$ cells, while "Thcommitted" CD27-expressing V $\delta 2^{+} \mathrm{T}$ cells were selectively depleted. A corresponding population of $\mathrm{CD} 27^{+} \mathrm{V} \delta 2^{+} \mathrm{T}$ cells was present in mucosal biopsies from $\mathrm{CD}$ patients and produced elevated levels of tumor necrosis factor (TNF)- $\alpha$ compared with controls (McCarthy et al. 2015). $\gamma \delta \mathrm{T}$ lymphocytes can attack target cells directly through their cytotoxic activity or indirectly through the activation of other immune cells. $\gamma \delta \mathrm{T}$ lymphocytes respond upon the recognition of stress antigens, which promotes cytokine production and regulates pathogen clearance, alleviates inflammation, and promotes tissue homeostasis in response to stress. Tissue-resident epithelial $\gamma \delta \mathrm{T}$ lymphocytes represent a major $\mathrm{T}$ cell population in epithelia and are ideally positioned to perform barrier surveillance and aid in tissue homeostasis and repair (Lee and Baldridge 2017). T cell receptor (TCR) $\gamma \delta$-bearing murine dendritic epidermal $\mathrm{T}$ cells are involved in the regulation of epidermal integrity and promote wound healing in the skin (Jameson et al. 2002). Intestinal intraepithelial $\gamma \delta \mathrm{T}$ cells regulate intestinal epithelial homeostasis (Boismenu and Havran 1994; Komano et al. 1995). $\gamma \delta$ T cells are also important in immune surveillance of the epithelium by providing the first line of defense against infectious pathogens attacking body surfaces and in regulating innate and adoptive immunity (Hayday and Tigelaar 2003; Komano et al. 1995; Mak and Ferrick 1998; Shiohara et al. 1996). Furthermore, $\gamma \delta$ T cells appear to down-regulate robust $\alpha \beta T$ cell-driven immune responses that often result in severe immunopathology (McVay et al. 1997). $\gamma \delta \mathrm{T}$ cells in the diseased mucosa have also been documented in UC patients (Yeung et al. 2000).

Recent investigations showed association of UC with an imbalance between effector $\mathrm{T}$ cells and regulatory $\mathrm{T}$ (Treg) cells. Interestingly, some clinical observations suggest the contribution of $\gamma \delta \mathrm{T}$ cells to the development of UC (Johnson et al. 2020; Mayer 2010; McCarthy and Eberl 2018).

Very little is known about colitis exacerbations especially from a clinical perspective. Exacerbations cannot be predicted based on preclinical animal models. However, it has been already reported that $\gamma \delta \mathrm{T}$ cells are involved in the pathogenesis of CD. Kadivar et al. (2016) showed that $\gamma \delta \mathrm{T}$ cells expressing both CD8 $\alpha$ and CD8 $\beta$ constitute a novel lymphocyte subset, which is strongly enriched within the gut and may play an important role in gut homeostasis and mucosal healing in IBD. Interestingly, Andreu-Ballester et al. (2011) found a decrease of lymphocytes in the 
peripheral blood of patients with $\mathrm{CD}$. This decrease was more evident and significant in the $\gamma \delta \mathrm{T}$ lymphocyte subsets, both overall and independently of the subsets of patients studied. CD $8^{+} \mathrm{T}$ lymphocytes were lowest in both the $\gamma \delta \mathrm{T}$ and $\alpha \beta$ T subsets (Andreu-Ballester et al. 2011). From an immunological point of view, the cause of exacerbation might be an increase in the pathological processes associated with the course of colitis, or a separate, as yet unknown pathological triggering process (Hanai et al. 2013).

Our previous experiments in mice demonstrated that surgical trauma in the abdomen induces $\gamma \delta \mathrm{T}$ lymphocyte migration from peripheral blood to peritoneal lymphoid organs (Gryglewski and Szczepanik 2017). Similarly we found in human that major surgery located in the peritoneal cavity (gastric and colorectal surgery) decreases the percentage of $\gamma \delta \mathrm{T}$ cells in peripheral blood. We suspect that similar process of T cell migration may occur during UC exacerbations (Gryglewski et al. 1997; Gryglewski and Szczepanik 2017).

To verify our hypothesis, we analyzed the difference between $\alpha \beta T$ and $\gamma \delta$ T cell numbers in the peripheral blood of patients with disease in remission or flaring, compared to healthy controls.

\section{Materials and Methods}

\section{Obtaining Blood Samples}

Five $\mathrm{ml}$ of venous blood was obtained from each patient. Each sample was immediately processed and analyzed.

\section{Reagents}

The following monoclonal antibodies (mAbs) were used: anti-TCR $\alpha / \beta$-FITC (clone WT 31), anti-TCR $\gamma / \delta$ - 1 -FITC (clone 11F2), anti-CD25-PE (clone M-A251), anti-CD54PE (clone LB-2) and anti-CD62L-PE (clone DREG-56). All mAbs and 10X concentrate FACS Lysing Solution were purchased from BD Biosciences (San Jose, CA, USA).

\section{Flow Cytometric Staining and Cell Analysis}

Fifty $\mu \mathrm{l}$ of whole blood was mixed with $20 \mu \mathrm{l}$ of the appropriate fluorochrome-conjugated $\mathrm{mAb}$ and incubated for $30 \mathrm{~min}$ at room temperature. The following staining panels were used: TCR $\alpha \beta$-FITC, TCR $\gamma \delta$-FITC, TCR $\gamma \delta$-FITC/ CD25-PE, TCR $\gamma \delta$-FITC/CD54-PE and TCR $\gamma \delta$-FITC/ $\mathrm{CD} 62 \mathrm{~L}-\mathrm{PE}$. The percentage of presented cell populations is referred to total analyzed lymphocytes.

When staining was finished, $450 \mu \mathrm{l}$ of $1 \times$ FACS Lysing Solution was added and samples were incubated for 20 min in the dark at room temperature. Then samples were washed and resuspended in PBS containing 1\% paraformaldehyde. All flow cytometric analyses were conducted within $2 \mathrm{~h}$ of fixation. Samples were run on Ortho Cytorone Absolute flow cytometer (Ortho Diagnostic Systems, Raritan, NJ). Immunocount II software was used for data acquisition and analysis.

\section{Statistical Analysis}

Data were analyzed using Statistica 10.0 PL software (licensed to Jagiellonian University Medical College). Descriptive statistics were used (mean, standard deviation, percentage distribution). Statistical significance was determined by $t$ test $(p<0.05)$.

\section{Patients' Characteristics}

One hundred and forty patients with histologically confirmed UC were included in this prospective case control study from 1999 to 2007 . We recruited UC patients admitted to the outpatient gastroenterology and surgery clinic of I Department of General Surgery, Gastroenterology, Oncology and Transplantology, exhibiting abdominal pain and bloody or mucous diarrhea. The majority of the patients studied were newly diagnosed, and some already treated with sulfosalazopirin and/or acetylsalicylic acid. We excluded individuals with prior cytostatic or steroid treatment from the study to avoid bias due to the effect of these drugs on peripheral blood lymphocyte counts. All patients underwent colonoscopy with UC confirmed histologically. At that time patients were divided into stable and exacerbated groups. Disease activity was measured using the Truelove, Witts and Montreal scale. For exacerbations of the disease, we monitored for severe symptoms according to the scale (Satsangi et al. 2006; Truelove and Witts 1955). Exclusion criteria included no consent from the patient or a history of steroid or cytostatic medication. Peripheral blood samples for immunological tests were obtained on the first day after accepting the patient for observation. All patients had a regular follow up and were instructed to contact the clinic every three months or if they experienced any complications (data not presented). We also recruited an additional 21 patients who developed UC exacerbations to the study over a threeyear period. Blood samples were taken for immunological tests from these participants and their results were added to the "exacerbation group", unless they were already treated with steroids or cytostatic drugs e.g. azathioprine. All other patients were included within the stable colitis group. Laboratory staff members (7) and patients with uncomplicated gallstones (50) prepared for surgery participated as healthy controls (Table 1). 


\section{Ethical Considerations}

The research protocol was approved by the Jagiellonian University Ethics Committee (registry number KBET/130/B/2014). The study was in accordance with the ethical standards defined in the 1964 Declaration of Helsinki and its amendments.

\section{Results}

Flow cytometry was used to determine the differences of $\alpha \beta \mathrm{T}$ and $\gamma \delta \mathrm{T}$ lymphocytes in peripheral blood between different groups of colitis and the healthy controls.

Data presented in Fig. 1 and Table 2 show that colitis exacerbation does not affect the percentage of $\alpha \beta \mathrm{T}$ cells $(62.7 \pm 1.6$; Group B) when compared to the percentage of $\alpha \beta$ T cells in patients with stable colitis $(65.5 \pm 1.4$; Group A) and in controls (62.6 \pm 2.4 ; Group C), (Group B vs. A and $\mathrm{C} ; p=\mathrm{NS}$ ).

Interestingly, results presented in Fig. 2 and Table 2 show differences between the $\gamma \delta \mathrm{T}$ in the exacerbations of colitis,
Table 1 Patients' characteristics

Fig. 1 The percent of $\alpha \beta$ T cells in peripheral blood. Blood samples from patients with stable colitis (A), colitis exacerbation (B) and from control group $(\mathbf{C})$ were stained with anti-TCR $\alpha / \beta$ FITC $m A b$ prior to FACS analysis. Group A: $n=88$, Group B: $n=52$, Group C: $n=57$. All error bars represent SD. $p=\mathrm{NS}$ (Student's $t$ test)

\begin{tabular}{lllrlll}
\hline Patients' group & Number & Gender M/F & Age (years) & $\begin{array}{l}\text { Disease dura- } \\
\text { tion (months) }\end{array}$ & $\begin{array}{l}\text { Montreal classifica- } \\
\text { tion (extent) E1/E2/ } \\
\text { E3 }\end{array}$ & $\begin{array}{l}\text { ASA/ } \\
\text { SSZ } \\
\text { (ever) }\end{array}$ \\
\hline Stable colitis & 88 & $41 / 47$ & $36 \pm 12$ & $63 \pm 37$ & $30 / 25 / 33$ & 57 \\
Exacerbations & 52 & $23 / 29$ & $43 \pm 15$ & $46 \pm 32$ & $9 / 23 / 20$ & 38 \\
Control & 57 & $30 / 27$ & $51 \pm 17$ & & & \\
Total & 197 & $94 / 103$ & $43.3 \pm 14.6$ & & & \\
\hline
\end{tabular}

E Extent according to the Montreal classification (E1-ulcerative proctitis, E2-left sided UC (distal UC), E3-extensive UC (pancolitis)), ASA/SSZ (ever) acetylsalicylic acid/sulfosalazopirin ever prescribed

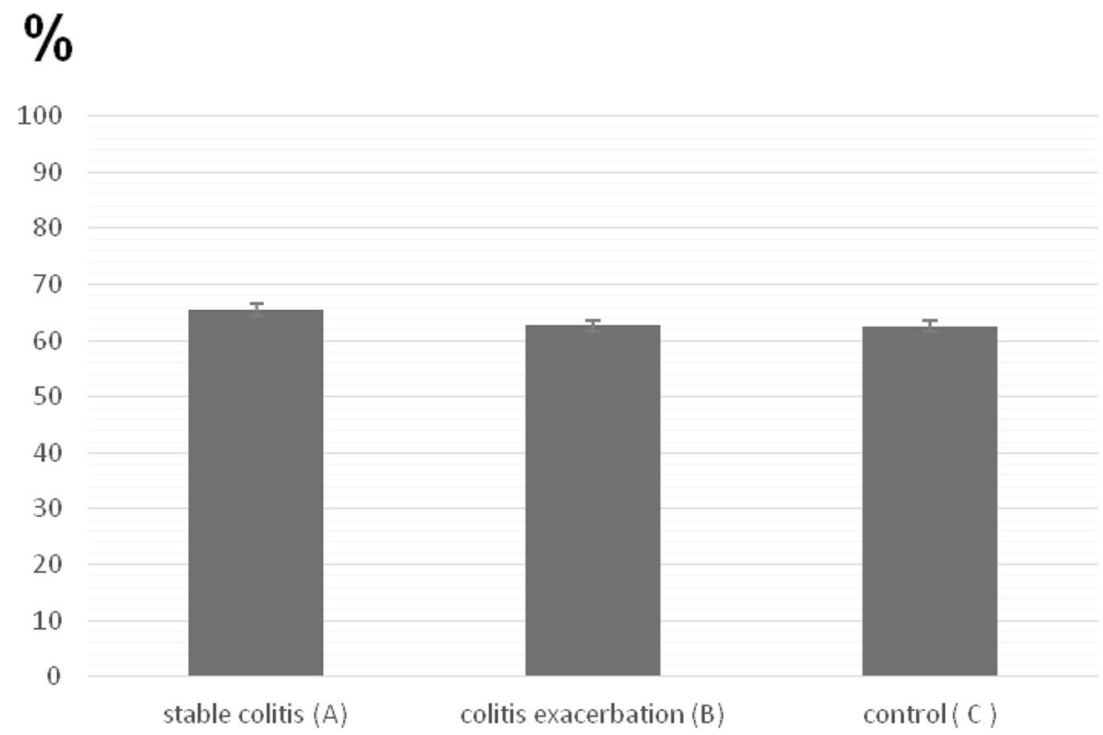

Table 2 The percentage of $\alpha \beta \mathrm{T}$ and $\gamma \delta \mathrm{T}$ cells in peripheral blood from patients with stable colitis (A), colitis exacerbations (B) and control (C)

\begin{tabular}{llll}
\hline & $\begin{array}{l}\text { The percentage of } \\
\alpha \beta \mathrm{T} \text { cells }\end{array}$ & $\begin{array}{l}\text { The percentage of } \gamma \delta \mathrm{T} \\
\text { cells }\end{array}$ & The ratio of $\alpha \beta \mathrm{T} / \gamma \delta \mathrm{T}$ cells \\
\hline Stable colitis & $65.5 \pm 1.4$ & $7.3 \pm 0.3$ & $9.0 \pm 3.0$ \\
Colitis exacerbations & $62.7 \pm 1.6$ & $2.0 \pm 0.1$ & $31.35 \pm 3.2$ \\
Control & $62.6 \pm 2.4$ & $5.2 \pm 0.25$ & $12.0 \pm 1.6$ \\
Statistical significance & - & $\begin{array}{l}\text { B vs. A and C } \\
p<0.001\end{array}$ & $\begin{array}{l}\text { B vs. A and C } \\
p<0.001\end{array}$ \\
\hline
\end{tabular}


Fig. 2 The percent of $\gamma \delta \mathrm{T}$ cells in peripheral blood. Blood samples from patients with stable colitis (A), colitis exacerbation (B) and from control group $(\mathbf{C})$ were stained with anti-TCR $\gamma / \delta$ 1-FITC $\mathrm{mAb}$ prior to FACS analysis. Group A: $n=88$, Group B: $n=52$, Group C: $n=57$. All error bars represent SD. ${ }^{*} p<0.001$ (Student's $t$ test)

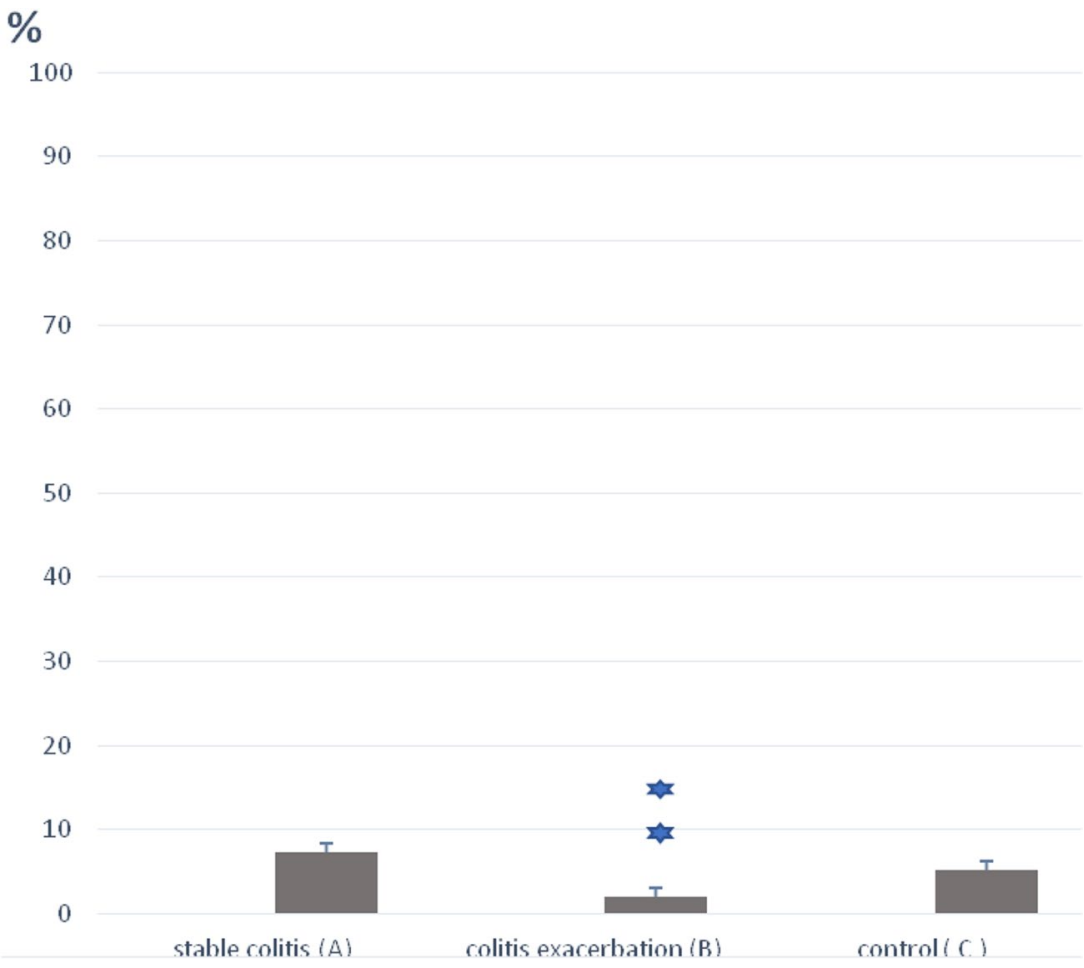

stable colitis and control group. They show that the percentage of $\gamma \delta$ Tcells was significantly lower in the peripheral blood of patients with colitis exacerbations ( $2.0 \pm 0.1$; Group B) compared to the control group (5.2 \pm 0.25 ; Group C) and the patients with stable colitis ( $7.3 \pm 0.3$; Group A), (Group $\mathrm{B}$ vs. A and $\mathrm{C}, p<0.001)$.

Additionally, in Fig. 3 and Table 2 we compared the ratio of $\alpha \beta T / \gamma \delta T$ lymphocytes in peripheral blood from patients with stable disease, diagnosed colitis exacerbations, and in the controls. The ratio $\alpha \beta T / \gamma \delta$ Twas significantly higher in the group of patients with colitis exacerbations $(31.35 \pm 3.2$; Group B) than the ratio $\alpha \beta \mathrm{T} / \gamma \delta \mathrm{T}$ in the group of patients with stable colitis $(9.0 \pm 3.0$; Group A), and the controls $(12.0 \pm 1.6$; Group C), (Group B vs. A and C, $p<0.001)$.

In addition, we evaluated cumulative counts of various cell surface markers on $\gamma \delta \mathrm{T}$ cells in the peripheral blood of patients with stable or exacerbated colitis and in controls.

To characterize $\mathrm{T}$ cell activation profile of $\gamma \delta \mathrm{T}$ lymphocytes, cells were additionally stained for expression of the following cell surface markers: CD25, CD54 and CD62L.
Fig. 3 The ratio of $\alpha \beta T$ to $\gamma \delta T$ cells in peripheral blood. Blood samples from patients with stable colitis (A), colitis exacerbation (B) and from control group $(\mathbf{C})$ were stained with either anti-TCR $\alpha / \beta$-FITC or anti-TCR $\gamma / \delta$-1-FITC $m A b$ prior to FACS analysis. Group A: $n=88$, Group B: $n=52$, Group $\mathrm{C}: n=57$. Then, the ratio of $\alpha \beta \mathrm{T}$ to $\gamma \delta \mathrm{T}$ cells was evaluated. All error bars represent SD.

$* * p<0.001$ (Student's $t$ test)

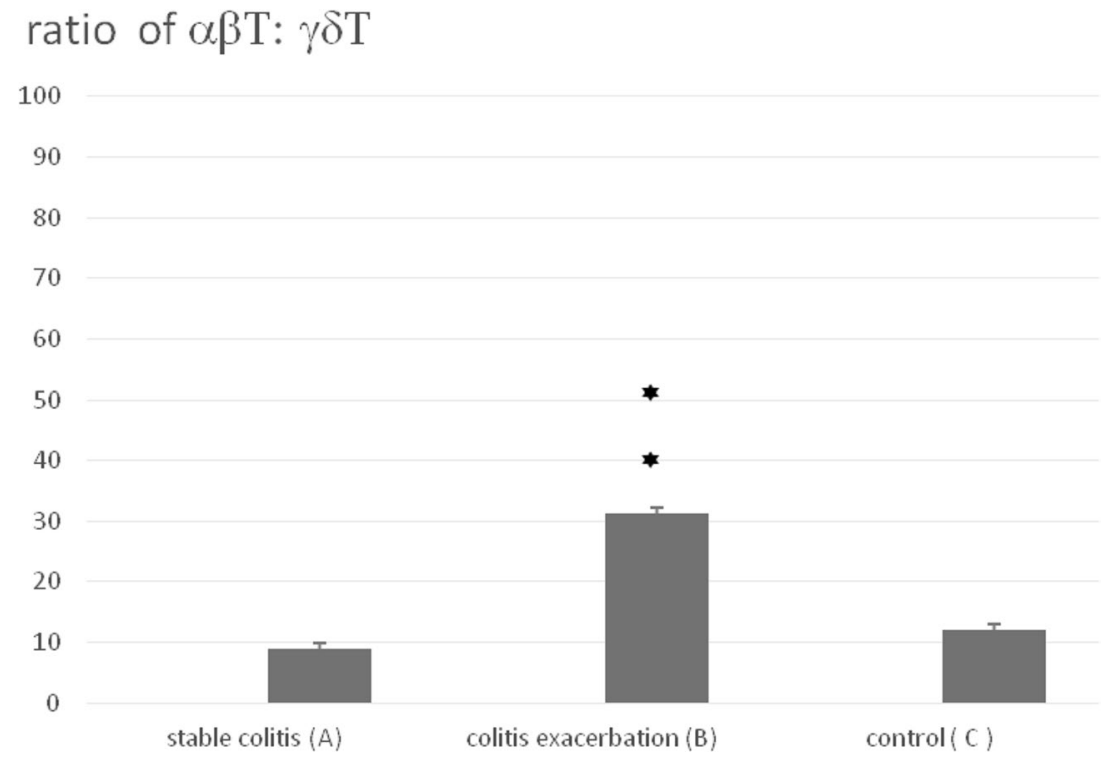


The data presented in Fig. 4 and Table 3 show the cumulative counts of $\gamma \delta \mathrm{T}$ lymphocytes expressing various surface markers in peripheral blood from patients with colitis exacerbations compared to the stable colitis group and the control group. We found increased percentage of $\gamma \delta \mathrm{T} \mathrm{CD} 25$ both in stable (12.06 \pm 6.6 ; Group A) and exacerbated colitis (15.08 \pm 1.3 ; Group B) groups when compared to the control group (1.1 \pm 0.3 ; Group C), (Groups A and B vs. C, $p<0.001)$.

Similarly percentage of $\gamma \delta \mathrm{T}$ CD54 cells was significantly increased in stable (42.2 \pm 7.1 ; Group A) and exacerbated $(52.7 \pm 2.8$; Group B) colitis groups compared to the control group (25.1 \pm 8.4 ; Group C), (Groups A and B vs. C, $p<0.01)$.

We observed lower percentages of $\gamma \delta \mathrm{T}$ cells expressing CD62L in the group of patients with stable colitis $(26.5 \pm 6.2$; Group A) compared to colitis exacerbation $(42.4 \pm 3.6$; Group B) and the control group $(44.4 \pm 5.0$; Group C), (Group A vs. B and C; $p<0.01$ ).

\section{Discussion}

There is a growing evidence supporting the idea that $\gamma \delta \mathrm{T}$ cells play an active multifaceted immunoregulatory role in the coordinated innate and adoptive immune responses to maintain the integrity of many organs containing epithelia especially in colon tissue (Boismenu and Havran 1994; Hayday and Tigelaar 2003; Jameson et al. 2002; Komano et al. 1995; Mayer 2010; Yeung et al. 2000). Recent investigations have indicated that UC is associated with several forms of immune imbalance, such as an imbalance between effector T cells and Treg cells (Havran 2000; Tonegawa et al. 1989).
Table 3 The percentage of $\gamma \delta \mathrm{T}$ lymphocytes expressing various surface markers in peripheral blood from patients with colitis stable colitis (A), colitis exacerbations (B) and control (C)

\begin{tabular}{|c|c|c|c|}
\hline & $\begin{array}{l}\text { Percentage } \\
\text { of } \gamma \delta \mathrm{T} \text { CD } 25 \\
\text { cells }\end{array}$ & $\begin{array}{l}\text { Percentage } \\
\text { of } \gamma \delta \mathrm{T} \text { CD } 54 \\
\text { cells }\end{array}$ & $\begin{array}{l}\text { Percentage of } \\
\gamma \delta T \text { CD62L } \\
\text { cells }\end{array}$ \\
\hline Stable colitis & $12.06 \pm 6.6$ & $42.2 \pm 7.1$ & $26.5 \pm 6.2$ \\
\hline $\begin{array}{l}\text { Colitis exacerba- } \\
\text { tion }\end{array}$ & $15.08 \pm 1.3$ & $52.7 \pm 2.8$ & $42.4 \pm 3.6$ \\
\hline Control & $1.1 \pm 0.3$ & $25.1 \pm 8.4$ & $44.4 \pm 5.0$ \\
\hline $\begin{array}{l}\text { Statistical signifi- } \\
\text { cance }\end{array}$ & $\begin{array}{l}\text { A and B vs. C } \\
p<0.001\end{array}$ & $\begin{array}{l}\text { A and B vs. C } \\
p<0.01\end{array}$ & $\begin{array}{l}\text { B and C vs. A } \\
p<0.01\end{array}$ \\
\hline
\end{tabular}

In this study we found significant decrease of $\gamma \delta \mathrm{T}$ but not $\alpha \beta T$ cells in the peripheral blood of patients with colitis during the exacerbation of the disease compared to the stable disease and the control group. In many publications the increased $\gamma \delta \mathrm{T}$ cell number has been documented in diseased mucosa probes in UC patients (Gryglewski et al. 1997; Hanai et al. 2008; Koch et al. 2010; Yu et al. 2007). Thus it is possible that observed decrease of $\gamma \delta \mathrm{T}$ cells in the peripheral blood in patients with colitis exacerbation results from the relocation of these cells to the diseased gut mucosa. Our observation of cells involved in immunoregulation, circulating from peripheral blood to mucosal tissue, and to other immunologically active organs is confirmed in the literature. Eastaff-Leung et al. (2010) report a decreased number of peripheral blood Treg cells associated with a reduced ratio of Treg to Th17 cells in peripheral blood. Interestingly, increased intestinal Foxp3 expression was observed in IBD patients what may suggest relocation of Treg cells from peripheral blood to the intestines (Eastaff-Leung et al. 2010).
Fig. 4 The percentage of $\gamma \delta \mathrm{T}$ lymphocytes expressing various surface markers (CD25, CD54, CD62L) in peripheral blood. Blood samples from patients with stable colitis (A), colitis exacerbation (B) and from control group $(\mathbf{C})$ were stained with anti-TCR $\gamma / \delta-1-F I T C$ and anti-CD25-PE or anti-CD54-PE or anti-CD62L-PE mAb prior to FACS analysis. Group A: $n=88$, Group B: $n=52$, Group C: $n=57$. All error bars represent SD. $* p<0.01, * * p<0.001$ (Student's $t$ test)

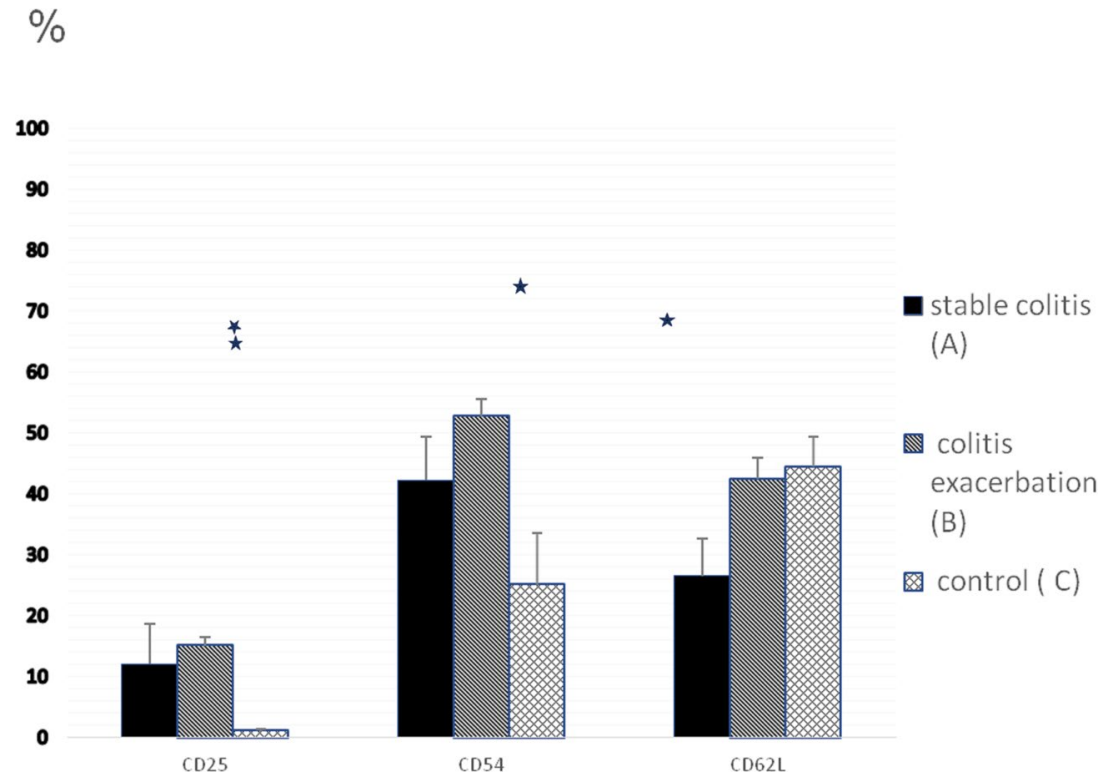


Based on our present observations it is difficult to define precisely the behavior of $\gamma \delta$ T cells during the exacerbation of colitis, mainly because the blood sample was collected once at unknown phase of exacerbation. Our observation allows only for general evaluation of the level of $\gamma \delta \mathrm{T}$ and $\alpha \beta T$ cells and provides the general difference between their level in exacerbations and stable colitis or remissions. It is important to note that some patients were treated pharmacologically and some of drugs (especially steroids and cytostatic agents) may influenced different blood cell levels. To avoid this, we excluded patients treated with steroids or cytostatics or with biologic therapy. Despite of this the fact that most of our patients were treated with the sulphasalazine or mesalazine may influence final results, and should be taken into the consideration. Nevertheless, our observation of patients with the exacerbation shown decreased $\gamma \delta \mathrm{T}$ blood cell numbers comparing to patients with stable colitis or controls, strongly suggesting these cells participation. There are reports showing involvement of $\gamma \delta T$ cells in course of IBD. Interestingly, the deficit of $\gamma \delta$ T cells was related with the severity and the risk for surgical relapse in CD patients (Andreu-Ballester et al. 2020). Additionally, animal studies show that resident $\gamma \delta \mathrm{T}$ cells are an early, innate-like source of IL-17 and that these cells amplify Th17 responses and exacerbate colitis development (Yurchenko et al. 2011). Moreover, it was observed that $\gamma \delta \mathrm{T}$ cells directly promote the generation of gut antigen-reactive $\mathrm{T}$ effector cells (Do et al. 2014). Thus, it is possible that observed in our study reduction of $\gamma \delta \mathrm{T}$ cells in peripheral blood during disease exacerbation might be caused by $\gamma \delta T$ lymphocyte migration from peripheral blood to peritoneal lymphoid organs and subsequent participation in disease progression. This is in line with our previous animal (Gryglewski et al. 1997) and human studies showing that surgery located in the peritoneal cavity (gastric and colorectal surgery) decreases the percentage of $\gamma \delta \mathrm{T}$ cells in peripheral blood (Gryglewski and Szczepanik 2017). Interestingly, in the group that had a large decrease in $\gamma \delta \mathrm{T}$ cells we found significantly more septic complications than in the group of patients with small $\gamma \delta \mathrm{T}$ cell decrease (Gryglewski et al. 2020). We would like to underline that in our work we evaluated percentage of all $\gamma \delta T$ cells without describing existing populations. As we mentioned in Introduction, $\gamma \delta \mathrm{T}$ cells can be classified into three populations: $\mathrm{V} \delta 1^{+}, \mathrm{V} \delta 2^{+}$and $\mathrm{V} \delta 3^{+}($Catalan-Serra et al. 2017; Davey et al. 2017). Interestingly, there are reports showing that human $\mathrm{V} \delta 2^{+} \mathrm{T}$ lymphocytes comprise two separate subsets, which have different biological activity. $\mathrm{V} \gamma 9^{+} \mathrm{V} \delta 2^{+} \mathrm{T}$ lymphocytes appear to represent an innate-like subset which is phosphoantigen-reactive, whereas $\mathrm{V} \gamma 9^{-} \mathrm{V} \delta 2^{+}$population represents unconventional $\mathrm{T}$ cell compartment that exhibits many of the hallmarks of an adaptive immunity (Davey et al. 2018). Further work is required to determine if $\gamma \delta \mathrm{T}$ cells investigated in our work exhibit hallmarks of innate-like or adaptive immunity. In addition, our analysis of various surface markers on $\gamma \delta \mathrm{T}$ cells shows increased percentage of $\gamma \delta \mathrm{T}$ CD25-positive cells in stable UC, as compared to controls, and an even greater increase of $\gamma \delta \mathrm{T} C \mathrm{CD} 25$-positive cells in colitis exacerbations. CD25 is the alpha chain of the IL-2 receptor which is a marker of the state activation of both $\alpha \beta \mathrm{T}$ and $\gamma \delta \mathrm{T}$ cell subsets induced by interactions of the TCR with its ligands (Migalovich Sheikhet et al. 2018). It was shown that IL-2 plays a role in generation of $\gamma \delta \mathrm{T}$ cells (Malik et al. 2016). Thus, increased expression of CD25 in both stable colitis and colitis exacerbation groups compared to control group may suggest increased activity of $\gamma \delta \mathrm{T}$ cells in UC patients despite of disease status.

Comparing expression of CD54 cell marker on $\gamma \delta \mathrm{T}$ positive cells, we found relatively higher percentage of CD54 expressing $\gamma \delta \mathrm{T}$ cells in colitis remission and even higher in exacerbations, when compared to the controls. CD54 (ICAM-1) plays an important role in leukocyte trafficking, immunological synapse formation, and numerous cellular immune responses. It is suggested that CD54 on T cells does not participate in $\mathrm{T}$ cell migration, but rather signals delivered into the $\mathrm{T}$ cell through CD54 are more likely involved in cell recognition or activation. Indeed, Chirathaworn et al. (2002) found that signaling of resting T cells through CD54 delivers a distinct costimulatory signal resulting in $\mathrm{T}$ cell activation and proliferation. Thus increased expression of CD25 and CD54 on $\gamma \delta T$ cells in colitis patients may suggest activation of these cells and their involvement in the disease. Finally, we found significant decrease of CD62L expressing $\gamma \delta \mathrm{T}$ cells in blood samples from patients with colitis remission when compared to patients with colitis exacerbation and the control group. CD62L expression on naive T cells is required for their efficient recirculation and compartmentalization between blood and lymph nodes (Hengel et al. 2003). Interestingly mucosal healing was reflected by significant increase of $\mathrm{CD} 62 \mathrm{~L}$ expression in mucosal $\mathrm{T}$ cells in patients in remission compared to those with active inflammation (Karlsson et al. 2014). Thus significant decrease of CD62L expressing $\gamma \delta \mathrm{T}$ in blood samples from patients with colitis remission may be resulting from the relocation of these cells to the gut mucosa. More recently, several other candidate cell-based biomarkers have emerged: CD8CD69 in both IBDs, CD4CD45RO and CD4HLADR in CD and CD4, Th2, Th17 and CD8HLADR in UC seem to be promising markers of remission or of the prediction of a therapeutic response to anti-TNF treatment (Dulic et al. 2020). Interestingly, Andreu-Ballester et al. (2020) found a relationship between lower $\gamma \delta$ T cell levels and risk of surgical relapse in CD. The lowest subsets observed in $\mathrm{CD}$ patients with surgical relapse were $\mathrm{CD} 3^{+} \gamma \delta, \mathrm{CD}^{+}{ }^{+} \mathrm{CD} 8^{+} \gamma \delta$ and $\mathrm{CD} 3^{+} \mathrm{CD} 56^{+} \gamma \delta \mathrm{T}$ cells, whereas the lowest levels of $\mathrm{CD} 3^{+} \gamma \delta$ and $\mathrm{CD} 3^{+} \mathrm{CD} 8^{+} \gamma \delta$ $\mathrm{T}$ lymphocytes were observed in the fistulizing phenotype (Andreu-Ballester et al. 2020). 
In summary, our observations indicate that the change in the number of $\gamma \delta \mathrm{T}$ lymphocytes in the peripheral blood occurs in patients during an exacerbation of UC. Understanding the temporal relationship between $\gamma \delta T$ cells and the exacerbation of colitis may identify important biomarkers for earlier diagnosis of disease flares. The more permanent observation of $\gamma \delta$ T cells in peripheral blood of patients with colitis might help in early recognition and treatment of exacerbations in patients with UC.

\section{Conclusion}

Exacerbation of ulcerative colitis results in a decreased percentage of $\gamma \delta \mathrm{T}$ cells in peripheral blood with increase of CD25, CD54 and CD62L expressing $\gamma \delta T$ cells. This may represent the effect of cell activation and migration, similar to that observed after the surgical trauma. We hope that this observation may help to predict exacerbations in colitis patients.

Acknowledgements This study was supported by The State Committee for Scientific Research 2003/501/KL/530/L Grant (Poland).

\section{Declarations}

Conflict of Interest The authors report no financial or personal relationships with people or organizations which could potentially and inappropriately influence their work and conclusions.

Open Access This article is licensed under a Creative Commons Attribution 4.0 International License, which permits use, sharing, adaptation, distribution and reproduction in any medium or format, as long as you give appropriate credit to the original author(s) and the source, provide a link to the Creative Commons licence, and indicate if changes were made. The images or other third party material in this article are included in the article's Creative Commons licence, unless indicated otherwise in a credit line to the material. If material is not included in the article's Creative Commons licence and your intended use is not permitted by statutory regulation or exceeds the permitted use, you will need to obtain permission directly from the copyright holder. To view a copy of this licence, visit http://creativecommons.org/licenses/by/4.0/.

\section{References}

Andreu-Ballester JC, Amigó-García V, Catalán-Serra I et al (2011) Deficit of gammadelta $\mathrm{T}$ lymphocytes in the peripheral blood of patients with Crohn's disease. Dig Dis Sci 56:2613-2622. https:// doi.org/10.1007/s10620-011-1636-8

Andreu-Ballester JC, Catalán-Serra I, Gil-Borrás R et al (2020) Gamma delta T cells as a predictor of surgical relapse of Crohn's disease. Clin Res Hepatol Gastroenterol 44:586-597. https://doi.org/10. 1016/j.clinre.2019.11.003

Armuzzi A, DiBonaventura MD, Tarallo M et al (2020) Treatment patterns among patients with moderate-to-severe ulcerative colitis in the United States and Europe. PLoS ONE 15:e0227914. https:// doi.org/10.1371/journal.pone.0227914

Boismenu R, Havran WL (1994) Modulation of epithelial cell growth by intraepithelial $\gamma \delta$ T cells. Science 266:1253-1255. https://doi. org/10.1126/science.7973709

Catalan-Serra I, Sandvik AK, Bruland T et al (2017) Gammadelta T cells in Crohn's disease: a new player in the disease pathogenesis? J Crohns Colitis 11:1135-1145. https://doi.org/10.1093/ecco-jcc/ jjx039

Chirathaworn C, Kohlmeier JE, Tibbetts SA et al (2002) Stimulation through intercellular adhesion molecule-1 provides a second signal for T cell activation. J Immunol 168:5530-5537. https://doi. org/10.4049/jimmunol.168.11.5530

Davey MS, Willcox CR, Joyce SP et al (2017) Clonal selection in the human V $\delta 1 \mathrm{~T}$ cell repertoire indicates $\gamma \delta$ TCR-dependent adaptive immune surveillance. Nat Commun 8:14760. https://doi.org/10. 1038/ncomms 14760

Davey MS, Willcox CR, Hunter S et al (2018) The human V82+ T-cell compartment comprises distinct innate-like $\mathrm{V} \gamma 9^{+}$and adaptive V $\gamma 9^{-}$subsets. Nat Commun 9:1760. https://doi.org/10.1038/ s41467-018-04076-0

Do JS, Visperas A, Freeman ML et al (2014) Colitogenic effector T cells: roles of gut-homing integrin, gut antigen specificity and $\gamma \delta$ T cells. Immunol Cell Biol 92:90-98. https://doi.org/10.1038/ icb. 2013.70

Dulic S, Toldi G, Sava F et al (2020) Specific T cell subsets can predict the efficacy of anti-TNF treatment in inflammatory bowel diseases. Arch Immunol Ther Exp 68:12. https://doi.org/10.1007/ s00005-020-00575-5

Eastaff-Leung N, Mabarrack N, Barbour A et al (2010) Foxp3+ regulatory T cells, Th17 effector cells, and cytokine environment in inflammatory bowel disease. J Clin Immunol 30:80-89. https:// doi.org/10.1007/s10875-009-9345-1

Gryglewski A, Szczepanik M (2017) The effect of surgical stress on postoperative $\mathrm{T} \alpha \beta$ and $\mathrm{T} \gamma \delta$ cell distribution. Immunol Invest 46:481-489. https://doi.org/10.1080/08820139.2017.1296859

Gryglewski A, Szczepanik M, Majcher P et al (1997) Different patterns of gamma -delta $\mathrm{T}$ and alfa- beta $\mathrm{T}$ cell redistribution in the mouse after gastrectomy. J Surg Res 73:137-142. https://doi.org/ 10.1006/jsre.1997.5220

Gryglewski A, Richter P, Majewska-Szczepanik M et al (2020) Postoperative complications in patients with a significant post-operative decrease in $\gamma \delta \mathrm{T}$ cells. ANZ J Surg 90:62-66. https://doi.org/ 10.1111/ans. 15435

Hanai H, Iida T, Takeuchi K et al (2008) Adsorptive depletion of elevated proinflammatory $\mathrm{CD} 14^{+} \mathrm{CD} 16^{+} \mathrm{DR}^{+}$monocytes in patients with inflammatory bowel disease. Am J Gastroenterol 103:1210 1216. https://doi.org/10.1111/j.1572-0241.2007.01714.x

Hanai H, Iida T, Ikeya K et al (2013) A new paradigm in ulcerative colitis: regulatory $\mathrm{T}$ cells are key factor which induces/exacerbates UC through an immune imbalance. Mol Immunol 54:173-180. https://doi.org/10.1016/j.molimm.2012.11.015

Hanauer SB (2006) Inflammatory bowel disease: epidemiology, pathogenesis, and therapeutic opportunities. Inflamm Bowel Dis 12(Suppl 1):S3-9. https://doi.org/10.1097/01.mib.0000195385. 19268.68

Havran WL (2000) A role for epithelial $\gamma \delta \mathrm{T}$ cells in tissue repair. Immunol Res 21:63-69. https://doi.org/10.1385/ir:21:2-3:63

Hayday A, Tigelaar R (2003) Immunoregulation in the tissues by $\gamma \delta$ T cells. Nat Rev Immunol 3:233-242. https://doi.org/10.1038/ nri1030

Hengel RL, Thaker V, Pavlick MV et al (2003) Cutting edge: L-selectin (CD62L) expression distinguishes small resting memory CD4+ $\mathrm{T}$ cells that preferentially respond to recall antigen. J Immunol 170:28-32. https://doi.org/10.4049/jimmunol.170.1.28 
Jameson J, Ugarte K, Chen N et al (2002) A role for skin $\gamma \delta$ T cells in wound repair. Science 296:747-749. https://doi.org/10.1126/ science. 1069639

Ji J, Huang Y, Wang XF et al (2016) Review of clinical studies of the treatment of ulcerative colitis using acupuncture and moxibustion. Gastroenterol Res Pract 2016:9248589. https://doi.org/10.1155/ 2016/9248589

Johnson MD, Witherden DA, Havran WL (2020) The role of tissueresident $\mathrm{T}$ cells in stress surveillance and tissue maintenance. Cells 9:686. https://doi.org/10.3390/cells9030686

Kadivar M, Petersson J, Svensson L et al (2016) CD $8 \alpha \beta+\gamma \delta$ T cells: a novel $\mathrm{T}$ cell subset with a potential role in inflammatory bowel disease. J Immunol 197:4584-4592. https://doi.org/10.4049/ jimmunol.1601146

Karlsson M, Linton L, Lampinen M et al (2014) Naïve T cells correlate with mucosal healing in patients with inflammatory bowel disease. Scand J Gastroenterol 49:66-74. https://doi.org/10.3109/00365 521.2013.853829

Kiesler P, Fuss IJ, Strober W (2015) Experimental models of inflammatory bowel diseases. Cell Mol Gastroenterol Hepatol 1:154-170. https://doi.org/10.1016/j.jcmgh.2015.01.006

Koch S, Kucharzik T, Heidemann J et al (2010) Investigating the role of proinflammatory $\mathrm{CD} 16+$ monocytes in the pathogenesis of inflammatory bowel disease. Clin Exp Immunol 161:332-341. https://doi.org/10.1111/j.1365-2249.2010.04177.x

Komano H, Fijiura Y, Kawaguchi M et al (1995) Homeostatic regulation of intestinal epithelia by intraepithelial $\gamma \delta$ T cells. Proc Natl Acad Sci USA 92:6147-6151. https://doi.org/10.1073/pnas.92. 13.6147

Laroux FS, Norris HH, Houghton J et al (2004) Regulation of chronic colitis in athymic nu/nu (nude) mice. Int Immunol 16:77-89. https://doi.org/10.1093/intimm/dxh006

Lee S, Baldridge MT (2017) Interferon-lambda: a potent regulator of intestinal viral infections. Front Immunol 8:749. https://doi.org/ 10.3389/fimmu.2017.00749

Mak TW, Ferrick DA (1998) The $\gamma \delta$ T-cell bridge: linking innate and acquired immunity. Nat Med 4:764-765. https://doi.org/10.1038/ nm0798-764

Malik S, Want MY, Awasthi A (2016) The emerging roles of gammadelta $\mathrm{T}$ cells in tissue inflammation in experimental autoimmune encephalomyelitis. Front Immunol 7:14. https://doi.org/10.3389/ fimmu.2016.00014

Mayer L (2010) Evolving paradigms in the pathogenesis of IBD. J Gastroenterol 45:9-16. https://doi.org/10.1007/s00535-009-0138-3

McCarthy NE, Eberl M (2018) Human $\gamma \delta$ T cell control of mucosal immunity and inflammation. Front Immunol 09:985. https://doi. org/10.3389/fimmu.2018.00985

McCarthy NE, Hedin CR, Sanders TJ et al (2015) Azathioprine therapy selectively ablates human V82+ T cells in Crohn's disease. J Clin Invest 125:3215-3225. https://doi.org/10.1172/JCI80840

McVay LD, Li B, Biancaniello R et al (1997) Changes in human mucosal $\gamma \delta \mathrm{T}$ cell repertoire and function associated with the disease process in inflammatory bowel disease. Mol Med 3:183-203. http://www.ncbi.nlm.nih.gov.nb5

Migalovich Sheikhet H, Villacorta Hidalgo J et al (2018) Dysregulated $\mathrm{CD} 25$ and cytokine expression by $\gamma \delta \mathrm{T}$ cells of systemic sclerosis patients stimulated with cardiolipin and zoledronate. Front Immunol 9:753. https://doi.org/10.3389/fimmu.2018.00753

Nielsen MM, Witherden DA, Havran WL (2017) $\gamma \delta$ T cells in homeostasis and host defence of epithelial barrier tissues. Nat Rev Immunol 17:733-745. https://doi.org/10.1038/nri.2017.101

Pastorelli L, Garg RR, Hoang SB et al (2010) Epithelial-derived IL-33 and its receptor ST2 are dysregulated in ulcerative colitis and in experimental Th1/Th2 driven enteritis. Proc Natl Acad Sci USA 107:8017-8022. https://doi.org/10.1073/pnas.0912678107

Sanchez-Munoz F, Dominguez-Lopez A, Yamamoto-Furusho JK (2008) Role of cytokines in inflammatory bowel disease. World J Gastroenterol 14:4280-4288. https://doi.org/10.3748/wjg.14.4280

Sartor RB (2006) Mechanisms of disease: pathogenesis of Crohn's disease and ulcerative colitis. Nat Clin Pract Gastroent Hepat 3:390-407. https://doi.org/10.1038/ncpgasthep0528

Satsangi J, Silverberg MS, Vermeire S et al (2006) The Montreal classification of inflammatory bowel disease: controversies, consensus, and implications. Gut 55:749-753. https://doi.org/10.1136/ gut.2005.082909

Shiohara T, Moriya N, Hayakawa J et al (1996) Resistance to cutaneous graft vs host disease is not induced in T cell receptor $\delta$ gene- mutant mice. J Exp Med 183:1483-1489. https://doi.org/ 10.1084/jem.183.4.1483

Tanaka J, Saga K, Kido M et al (2010) Proinflammatory Th2 cytokines induce production of thymic stromal lymphopoietin in human colonic epithelial cells. Dig Dis Sci 55:1896-1904. https://doi. org/10.1007/s10620-009-0979-x

Tonegawa S, Berns A, Bonneville M et al (1989) Diversity, development, and probable functions of $\gamma \delta$ T cells. Cold Spring Harbor Symp Quant Bio 54(Pt 1):31-44. https://doi.org/10.1101/sqb. 1989.054.01.005

Truelove SC, Witts LJ (1955) Cortisone in ulcerative colitis; final report on a therapeutic trial. Br Med J 2:1041-1048. https://doi. org/10.1136/bmj.2.4947.1041

Yeung MM-W, Melgar S, Baranov V et al (2000) Characterization of mucosal lymphoid aggregates in ulcerative colitis: immune cell phenotype and TCR- $\gamma \delta$ expression. Gut 47:215-222. https://doi. org/10.1136/gut.47.2.215

Yu QT, Saruta M, Avanesyan A et al (2007) Expression and functional characterization of FOXP3 + CD4+ regulatory T cells in ulcerative colitis. Inflamm Bowel Dis 13:191-199. https://doi.org/10. 1002/ibd.20053

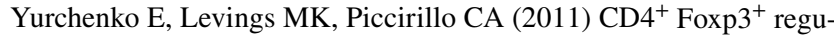
latory T cells suppress $\gamma \delta$ T cell effector functions in a model of T cell-induced mucosal inflammation. Eur J Immunol 41:34553466. https://doi.org/10.1002/eji.201141814

Zimmermann J, Kühl AA, Weber M et al (2016) T-bet expression by Th cells promotes type 1 inflammation but is dispensable for colitis. Mucosal Immunol 9:1487-1499. https://doi.org/10.1038/mi. 2016.5

Publisher's Note Springer Nature remains neutral with regard to jurisdictional claims in published maps and institutional affiliations. 